TITLE:

\title{
A STUDY ON THE GERMINATION OF CARPOSPORES OF DUDRESNAYA JAPONICA OKAMURA (RHODOPHYTA)
}

\author{
$\operatorname{AUTHOR}(\mathrm{S})$ : \\ Umezaki, Isamu
}

\section{CITATION:}

Umezaki, Isamu. A STUDY ON THE GERMINATION OF CARPOSPORES OF DUDRESNAYA JAPONICA OKAMURA (RHODOPHYTA). PUBLICATIONS OF THE SETO MARINE BIOLOGICAL LABORATORY 1968, 16(4): 263-272

ISSUE DATE:

1968-12-27

URL:

http://hdl.handle.net/2433/175550

RIGHT: 


\title{
A STUDY ON THE GERMINATION OF CARPOSPORES OF DUDRESNAYA JAPONICA OKAMURA (RHODOPHYTA) ${ }^{1)}$
}

\author{
ISAMU UMEZAKI \\ Department of Fisheries, Faculty of Agriculture, Kyoto University, Maizuru
}

With Plates $X I X-X X$ and 5 Text-figures

Dudresnaya japonica OKamura (Dumontiaceae, Cryptonemiales, Rhodophyta) is a Japanese endemic species and is distributed on the southern Pacific coast of Honshu, on the western coast of Kyushu and on Hachijo Islands. Another species of Dudresnaya, D. minima Okamura, is known in Japan.

Studies on the carposporophytes of $D$. japonica and $D$. minima were made by Hirose (1949) and by Kawashima (1959), respectively.

OKAMURA (1908), who found the germination of carpospores within the mother body of $D$. japonica, illustrated and explained in his Icones, Plate 42 , that after the division of the spore, irregularly branched filamentous embryos formed an aggregated mass and soon developed into a young plant. On the other hand, Killian (1914), who cultured carpospore germlings of Dudresnaya sp., reported that a prostrate disc was formed and erect threads originating from the disc grew to a mature thallus. On the basis of KILLIAN's report, INOH (1947) reported that the germination mode of Dudresnaya sp. might belong to "mediate discal type."

Since OKamura's and Killian's publications no one has engaged in studies on the germination of spores in species of Dudresnaya, in spite of the fact that there are many questions needing answers. Moreover, an interesting problem on the life history of Dudresnaya japonica in which no tetrasporphyte is known also remained unsolved. So, in order to study a developmental process from germination of spore to mature thallus the writer has engaged in a culture experiment of the germlings from carpospores of D. japonica. From results of the study he has found a few interesting facts which are mentioned below.

\section{Materials and Methods}

In April 1967 and in April 1968 the writer collected the plants of Dudresnaya japonica OKAMura with mature cystocarps at Shirahama, Wakayama Prefecture, where the Seto Marine Biological Laboratory, Kyoto University is situated, The materials

1) Contributions from the Seto Marine Biological Laboratory, No. 494.

Publ. Seto Mar. Biol. Lab., XVI (4), 263-272, 1968. (Article 18) 
collected were brought back to the laboratory of the Department of Fisheries, Faculty of Agriculture, Kyoto University at Maizuru, where the present culture experiments have been carried out.

The material was cut into pieces about $5 \mathrm{~mm}$ long. The pieces of the plant were carefully washed in sterilized sea water to remove minute epiphytic organisms and other contaminants. One piece of the material washed was put in a watch-glass containing sterilized sea water. After ten to twenty hours numerous carpospores were discharged into the water. Then, the discharged spores were transferred by means

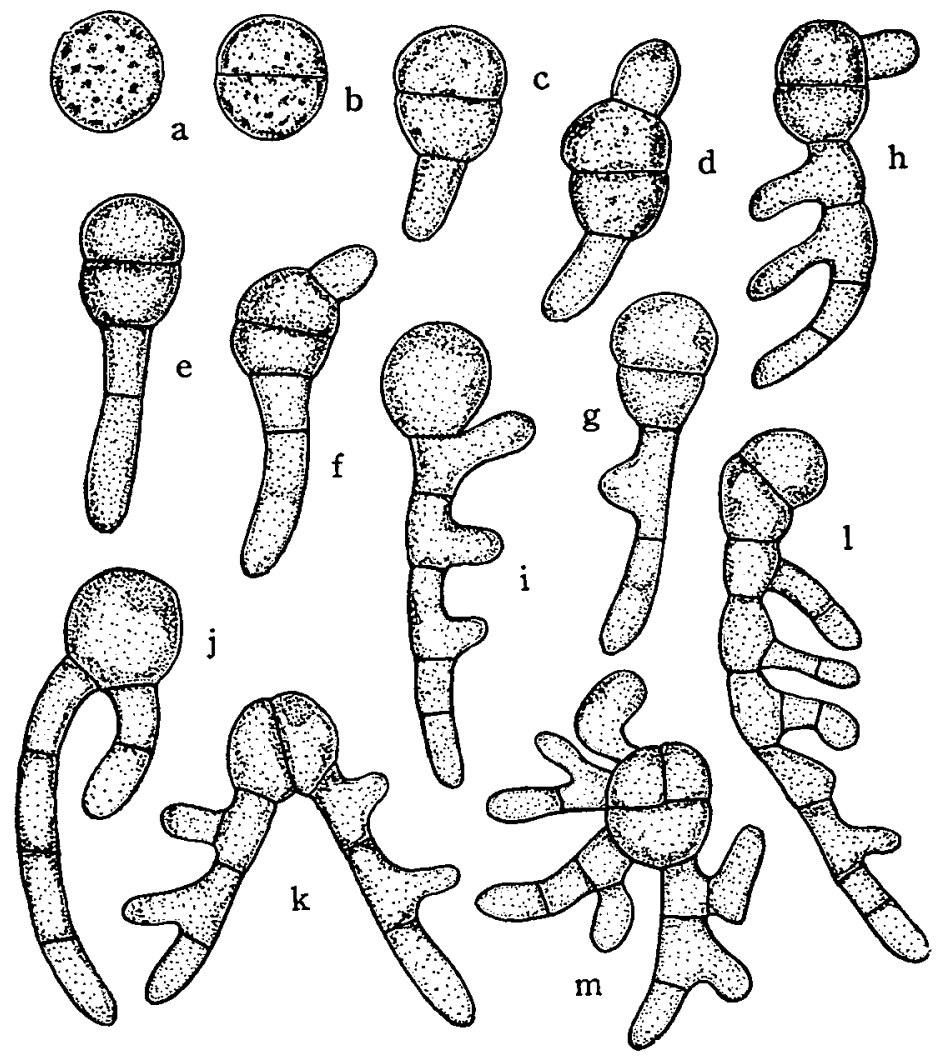

Fig. 1. Carpospore and its germination at various stages. $\times 600$.

of a micropipette to a $200 \mathrm{ml}$ ERLENMEYER flask on the inner bottom of which pieces of cover slips were laid, and to test-tubes. The flasks and test-tubes were stoppered with cotton by the same procedure as for bacteriological technique. Provasoli's enriched sea water medium, SWII solution, was used. The medium was changed once a week or two weeks. Some cultures were placed near windows covered with thin tracing papers in order to avoid direct rays of the sun and the others were controlled under 24 hours illumination daily of cocl-white fluorescent lamps (about 1000 lux). Both 
the cultures were grown at room temperature. Some of cultures have been maintained for more than one year in culture vessels under these laboratory conditions.

\section{Observations}

The discharged carpospores were naked. For a while after liberation they exhibited amoeboid movement. After ceasing movement, they fastened to the substratum and became spherical and enveloped with a hyaline membrane. They measured 15$17 \mu$, mostly $15 \mu$ in diameter. The spore contained numerous elliptical floridean strach grains and one or two parietal chromatophores. (Text-fig. 1 a, 2 a; pl. XIX, fig. 1). No pyrenoid was observed. After one day most of the spores divided into two equal cells by a transverse division. (Text-figs. 1 b and $2 b$; pl. XIX, fig. 2). Sometimes, abnormal cases were observed: The two-celled body was again divided into three or four cells by planes parallel or oblique to the first wall. (Text-fig. 2; pl. XIX, fig. 2).
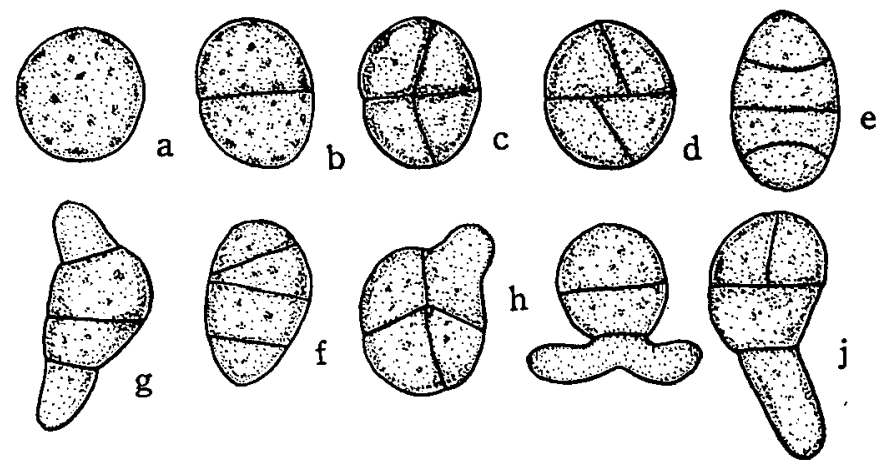

Fig. 2. Carpospore and its abnormal germination at early stages. $\times 600$.

Mostly two-, rarely three- or four-celled bodies, or initial cells of prostrate disc, remained recognizable for a fairly long period within the prostrate system. As was observed in Dudresnaya sp. by KILLIAN (1914) the spore body or the initial cell rarely divided on production of the creeping filament. (Text-fig. $1 \mathrm{i}, \mathrm{j}$ ). In two-day culture the one or two cells of two-celled body protruded at one or two poles, respectively, and each protuberance elongated itself. At stages from five to seven days it gave rise to a creeping filament composed of three to ten cells. (Text-fig. l c-f, j, $3 \mathrm{a}$ ). This is a peculiar characteristic of the germination of spores of Dudresnaya japonica. A similar mode of development is known in the genus Halymenia (H. dichotoma, Killian 1914; H. agardhii, INOH 1947). Three- or four-celled bodies also produced from one to four prostrate filaments usually laterally, or sometimes basally. (Text-fig. $1 \mathrm{~m}, 2 \cdot \mathrm{h}, \mathrm{j}$ ). In oneweek-old culture some or all cells of the creeping filament branched to form new cells on one or both sides. (Text-fig. $1 \mathrm{~g}-\mathrm{i}, \mathrm{k}-\mathrm{m}, 3 \mathrm{~b}$ ). Sometimes, the cells of the prostrate filament branched in dichotomous fashion. Afterwards, the prostrate filaments richly 
branched to form a compact mass. After ten days the prostrate system became a monostromatic circular disc and was enveloped with a colorless, gelatinous membrane distinctly visible under the microscope. (Text-fig. $3 \mathrm{~h}$; pl. XIX, fig. 4, 5). At twoweek-old stage the disc consisted of cells from several dozens to about one hundred in

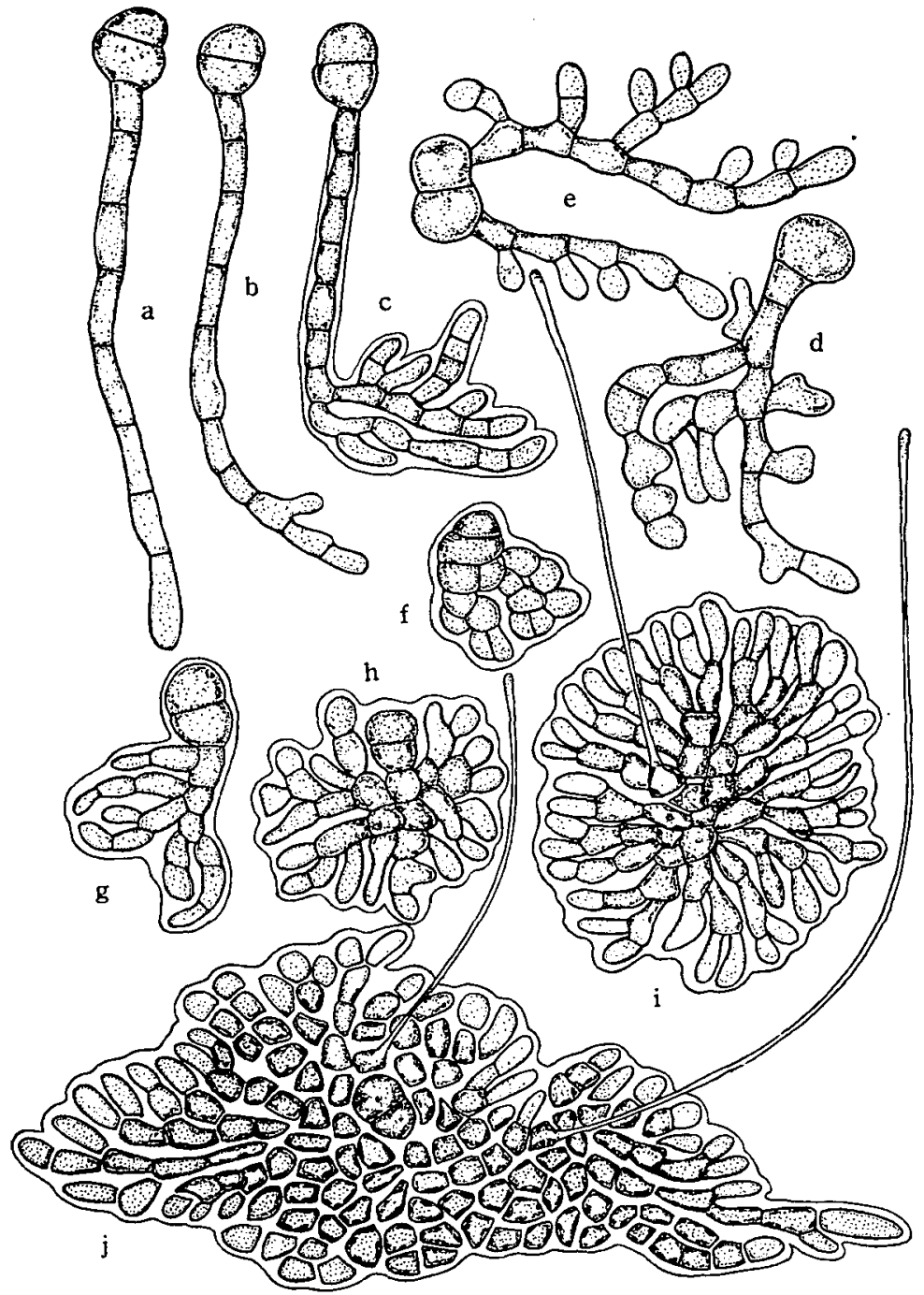

Fig. 3. Carpospore germlings at early stages in development. a-e $\times 500, \mathrm{f}-\mathrm{j} \times 330$.

number. At that stage colorless hairs appeared from cells in the middle part of the disc, arising singly from the cells. With the growth of the disc, hairs increased in number. The hairs are $2-2.5 \mu$ broad, up to $350 \mu$ long, and with the protoplasm only at their tips. (Text-fig. $3 \mathrm{i}, \mathrm{j}, 4$; pl. XIX, fig. 6-8). In two-month-old culture axial 
cells became visible on the prostrate disc. First, uniseriate filaments running from the center to the margin of a disc began to elongate themselves and then developed into axial cells, which were easy to distinguish from other cells by their size and shape. (Text-fig. $3 \mathrm{j}$ ). In two weeks following this, the prostrate system became larger in diameter, having from two to several axis some of which gave rise to further erect threads. At this stage prostrate discs grew very irregular in shape, probably due to unequal growth of the marginal cells. The lower surface of the prostrate disc adhered

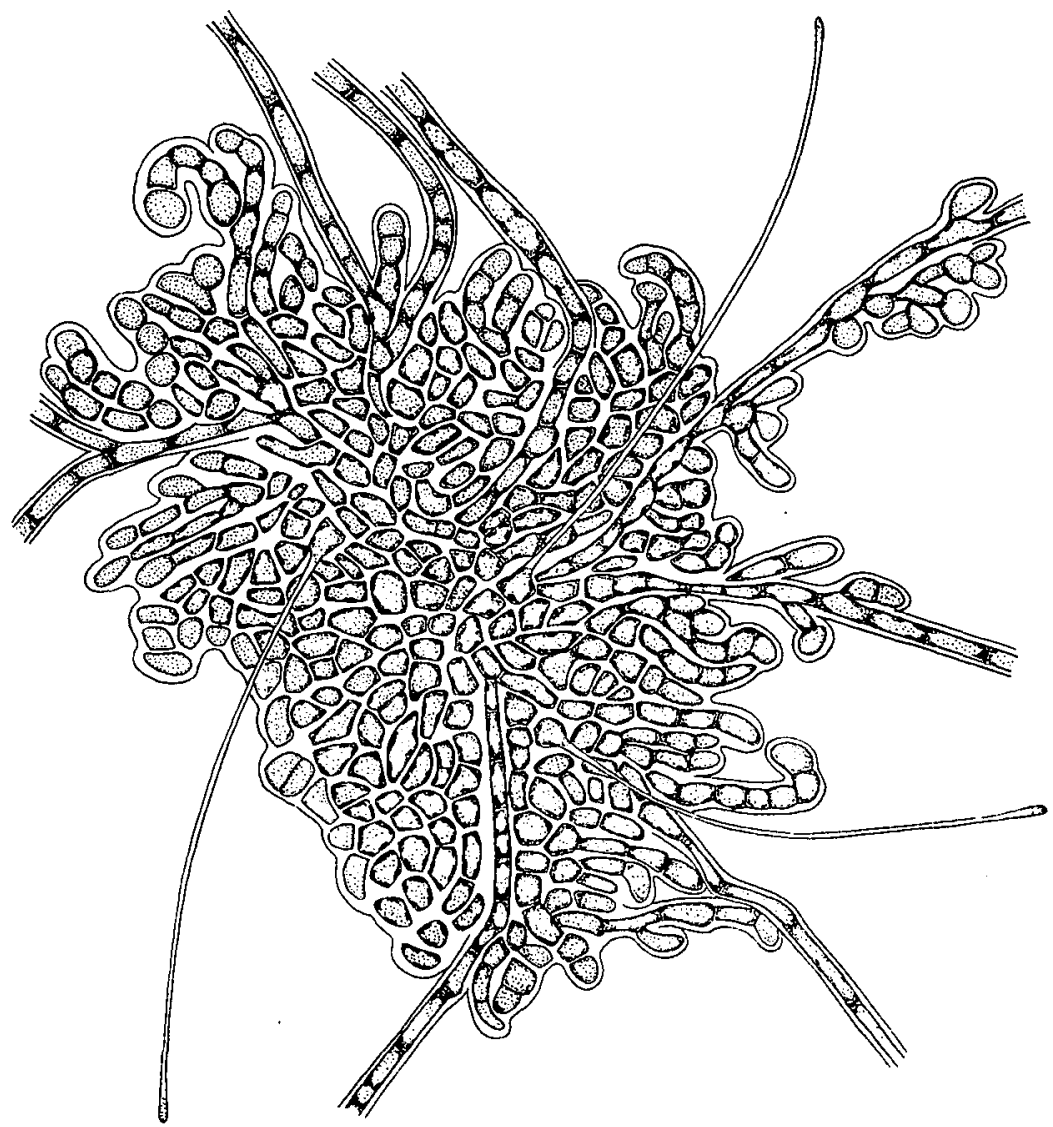

Fig. 4. A prostrate disc from which erect threads are sent out. $\times 270$.

firmly to the substratum. (Text-fig. 4). The cells of the prostrate system were quadrate to hexagonal in surface view, 3.5-6 $\mu \times 5-12.5 \mu$ in size, each having two to several parietal chromatophores. (Text-fig. 4,5f). The marginal cells of the disc were a little larger than the inner ones, ovoid or clavate in shape. The axial cells were cylindrical, 5-6 $\mu$ in diameter, 12-27.5 $\mu$ in length, 2-4.5 times as long as the diameter. In cultures 2.5-3 months old most of the axes in a disc grew out directly into erect threads the cells of which closely resembled the axial cells, showing a heterotrichous 


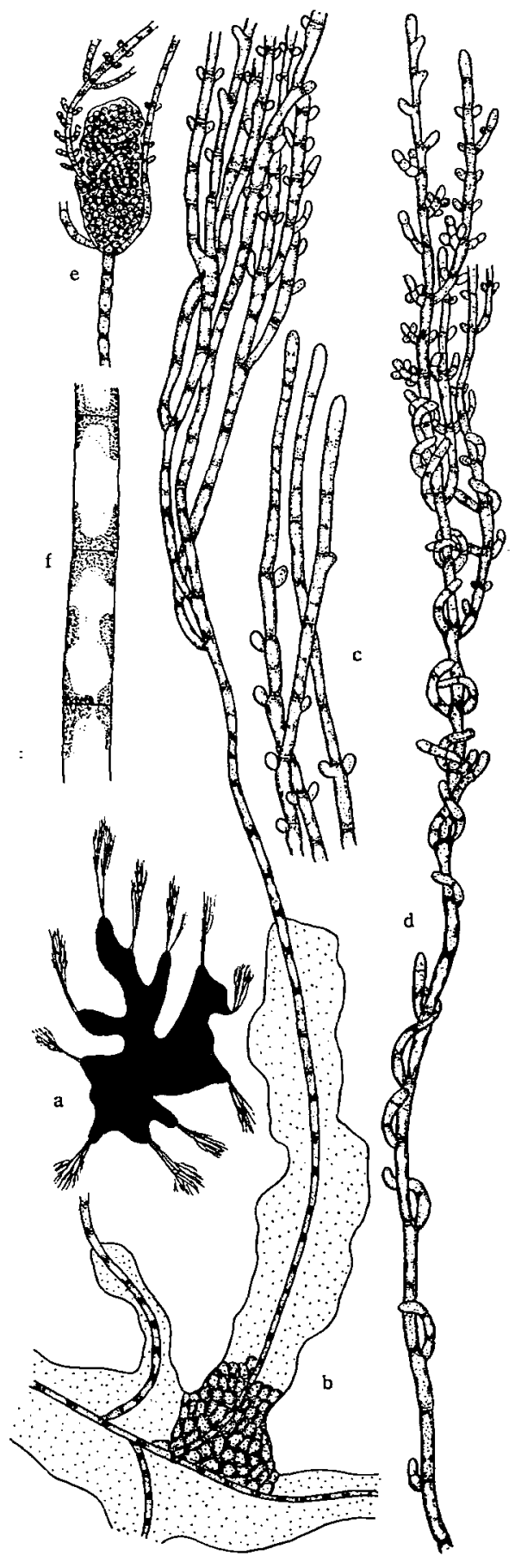

habit. (Pl. XX, fig. 1, 2). When the culture stage proceeded further, several erect filaments originating from the prostrate system stood at right angles to the disc, and began to branch and the many fasciculate branched laterals became straight upwards, all with cylindrical cells. (Text-fig. 4, $5 \mathrm{a}, \mathrm{b}$; pl. XX, fig. 3,4). After three to four months erect threads reached $1-2.5 \mathrm{~mm}$ long. This growth is effected by apical cells. The cells of the erect thread were 5-10 $\mu$ broad, 20-62 $\mu$ long, cylindrical in shape. Since this time most of the cells from the middle part of an erect thread upwards began to branch and formed short laterals with limited growth arising from the upper ends of each cell. (Pl. XX, fig. 5). After this time the short laterals further elongated to bend in irregular manner, some of them surrounding their erect threads or twisting about their adjacent erect threads. Sometimes, short laterals played an important role to form a loose bundle composed of several erect threads which twisted about one another. (Text-fig. $5 \mathrm{~d}$ ). After one year, monostromatic prostrate system became $5 \mathrm{~mm}$ or a little more in diameter and erect threads reached a length of 5-7 $\mathrm{mm}$. Even in this culture erect threads did not produce a parenchymatous structure, but the majority of them grew freely separated from one another. Sometimes, the erect threads formed a densely juxtaposed bundle, although a uniaxial condition was not recognizable on it. Moreover, the branches

Fig. 5. a, habit of a germling at five-month stage. $\times 16$. $b$, part of a prostrate disc and erect threads arising from the disc. $\times 150$. $c$, upper part of erect threads. $\times 140$. d, part of an erect thread from which short laterals are produced. $\times 140$. $e$, swollen body on erect threads. $\times 70 . \quad f$, part of an erect thread showing chromatophores within the cells. $\times 400$. 
of the short laterals of limited growth formed a loosely compact envelope to the fasciculate bundle; after further development the envelope may develop into a cortical layer. (Pl. XX, fig. 6, 7). Rhizoids, which are characteristic components in adult plants of the genus Dudresnaya, were not found produced in the culture at this stage. In one-year-old culture swollen bodies were occasionally found produced on entangled erect threads. The bodies are constructed by irregularly entangled short laterals of limited growth and erect threads, measuring up to $500 \mu$ in size. (Text-fig. $5 \mathrm{e} ; \mathrm{pl}$. XX, fig. 8,9). Even at one year or a little older stage the erect threads did not grow into a mature plant as seen in the sea. No reproductive organs were produced in culture. Germlings, which have been cultured under 24 hours illumination daily of fluorescent lamps grew much better than those placed near windows, although no morphological differences between the two cultures were found.

\section{Discussion}

OKamura (1908), who found germlings from carpospores in different stages within the mother body of Dudresnaya japonica, reported that after the division of the spore irregularly branched filaments formed an aggregated mass and soon developed into a yong plant. From his culture experiment of carpospore germlings in Dudresnarya sp. Killian (1914) reproted that after germination the germlings formed several-celled prostrate system and at this stage their spore bodies and older cells of their discs degenerated. On the basis of KILIIAN's report INOH (1947) designated the germination mode of spores in Dudresnaya sp. as mediate discal type. Judging from Killian's report it seems that the spore bodies of Dudresnaya sp. degenerated due to unfavorable conditions. According to Killian, upon germination the spore bodies or initial cells did not divide. Such undivided spores were also found in the present study, although the majority of spores divided into two, some into three or four cells from which creeping filaments grew up. This is a special feature for the germination of spores in genera Dudresnaya (KILlian 1914; present work) and Halymenia (KILlian 1914; INoH 1947). Okamura (1908) also illustrated early germlings from divided spores. From the present culture it was shown that the divided spore bodies or initial cells of disc remained recognizable in the disc. Killian reported that the prostrate disc grew mainly from its foward margin. However, the present study shows that in cases in which spore body did not divide, or in which the postrate filament was produced only laterally from initial cells the prostrate system at its early stage remained mainly unilateral. (Text-fig. 3 a-c, $\mathrm{f}-\mathrm{g}$ ). Usually, the prostrate system grew around initial cells of the disc, ultimately becoming a circular disc at the center of which the initial cells persisted.

According to KILLIAN most of the erect filaments terminated in hairs. On the other hand, in Dudresnaya japonica hairs were not found on the erect thread, but only on the prostrate system. (Text-fig. $3 \mathrm{i}, \mathrm{j}, 4$; pl. XIX, fig. 6-8). This is one of dif- 
ferences concerning spore germination between the two species. In Dudresnaya minima the apical cells of the cortex have hairs, according to KAWASHIMA's figure (1959, Fig. A 1). But, in D. japonica no hairs are known (OKamura 1908).

As mentioned above, Okamura considered that branched filamentous embryos originating from carpospores might directly develop into young plants without forming prostrate system. The branched filaments shown by Okamura (Icones, Plate 42, fig. 16) appear to be erect threads, although their prostrate disc is not figured. KILlian, on the other hand, observed a prostrate system from which erect threads originated. And he explained without giving a detailed process of development that erect threads developed into mature thalli. The present study agrees with KiLlian's observation. From a fact that a cortex-like layer was found forming on the fasciculate bundle of erect threads, it seems that the cortex of mature thalli is formed from the branches of the short laterals of limited growth. A uniaxial condition, which is an important characteristic of the genus Dudresnaya, was not recognizable even in one-year-old culture, although one of the erect threads forming a densely juxtaposed bundle may develop into a central axis after further development. Formation of swollen bodies, which were found produced on erect threads and which had a pseudo-parenchymatous structure, shows that short laterals of limited growth and erect threads may develop into mature thalli. Further study of developmental process to young plant from erect thread is essential.

An early developmental mode of germination of carpospores in Dudresnaya japonica closely resembles Halymenia dichotoma (KILLIAN 1914) and H. agardhii (INOH 1947). Both members of the Cryptonemiaceae, they were designated as "diprotocellular type" by INOH (1947). D. japonica may be included in this type.

In the Dumontiaceae there are two types of spore germination: Immediate discal type to which Dumontia filiformis (Kylin 1917) and D. incrassata (Rosenvinge 1917) belong; and diprotocellular type in which Dudresnaya sp. (KILLIAN 1914) and $D$. japonica (present work) are included. The spore of Dumontia filiformis (35-45 $\mu$, KyLIN 1917) is much larger in size or two times or a little larger than that of Dudresnaya japonica (15-17 $\mu$, present work). From the data there appears to be a distinct difference between the two genera. Moreover, it is phylogenetically of interest that Halymenia in the Cryptonemiaceae and Dudresnaya in the Dumontiaceae are both similar not only in spore size but also in the mode of spore germination.

\section{Summary}

1. Germination of carpospores of Dudresnaya japonica OKamura which was collected from Shirahama, Wakayama Prefecture was studied.

2. Germination mode of the spore was of INOH's diprotocellular type.

3. After germination the early germling produced a monostromatic prostrate disc and then this sent out erect threads, showing a heterotrichous habit.

4. Erect threads showed a tendency to develop into a mature thallus after one 
year in culture.

\section{Acknowledgments}

The writer wishes to express his cordial thanks to Dr. Y. YonedA for his kind guidance during the course of this work. The writer is also very thankful to Dr. I. A. Аввотт of the Hopkins Marine Station of Stanford University, Pacific Grove for her careful reading of the manuscript.

\section{REFERENCES}

Hirose, H. 1949. Contribution to the knowledge of the development of the female organ of Dudresnaya japonica OKamura. Trans. Sapporo Nat. Hist. Soc. 18(1/2): 8-12. (In Japanese).

INOH, S. 1947. The Germination of Marine Algae. 255 pp., Tokyo. (In Japanese).

KawaShIMA, S. 1959. On the structure of the female organ and its development of Dudresnaya minima Okamura. Bull. Jap. Soc. Phycol. 7(1): 11-18. (In Japanese).

Killian, K. 1914. Über die Entwicklung einiger Florideen. Zeitschr. f. Bot. 6: 209-279.

Kylin, H. 1917. Úber die Keimung der Florideensporen. Arkiv. f. Botanik, 14(22): 1-25.

Oramura, K. 1908. Icones of Japanese Algae, 1(9): 209-232, pls. 41-45.

Rosenvinge, L.K. 1917. The Marine Algae of Denmark. Part II. Rhodophyceae II (Cryptonemiales), pp. 155-283. 


\section{EXPLANATION OF PLATES XIX-XX}

Plate XIX. 1, carpospores. $\times 200.2$, carpospores being divided into two-four cells. $\times 400.3$, one or two protuberances being produced from the initial cells of disc. $\times 500.4,5$, prostrate discs at tenday stage. $4 \times 350,5 \times 400.6$, two prostrate discs bearing hairs at two-week stage. $\times 200$. 7, prostrate disc at three-week stage. $\times 200.8$, prostrate discs at one-month stage. $\times 50$.

Plate XX. 1, prostrate discs at three-month stage. $\times 70.2$, marginal portion of a prostrate disc at three-month stage. $\times 150.3$, marginal portion of a prostrate disc at four-month stage showing erect threads sending out from the disc. $\times 150.4$, part of erect threads at four-month stage. $\times 200$. 5 , part of erect threads at five-month stage. $\times 200.6,7$, formation of a bundle composed of erect threads. $\times 200.8,9$, swollen body being produced on erect threads. $\times 150$. 
Publ. Seto Mar. Biol. Lab., XVI (4), $1968 . \quad$ Plate XIX

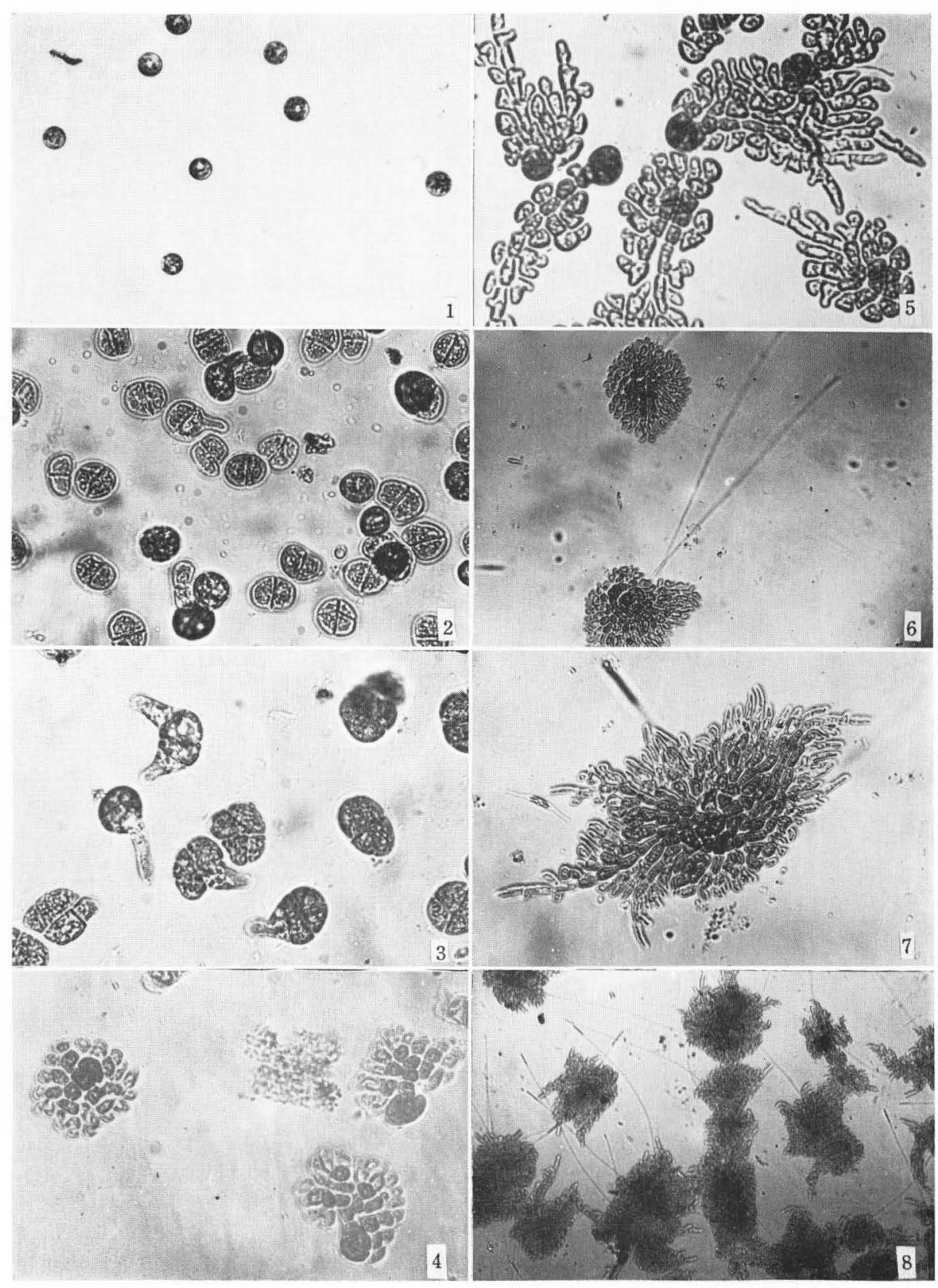

I. UMEZAKI; Germination of Carpospores of Dudresnaya Japonica 
Publ. Seto Mar. Biol. Lab., XVI (4), 1968.
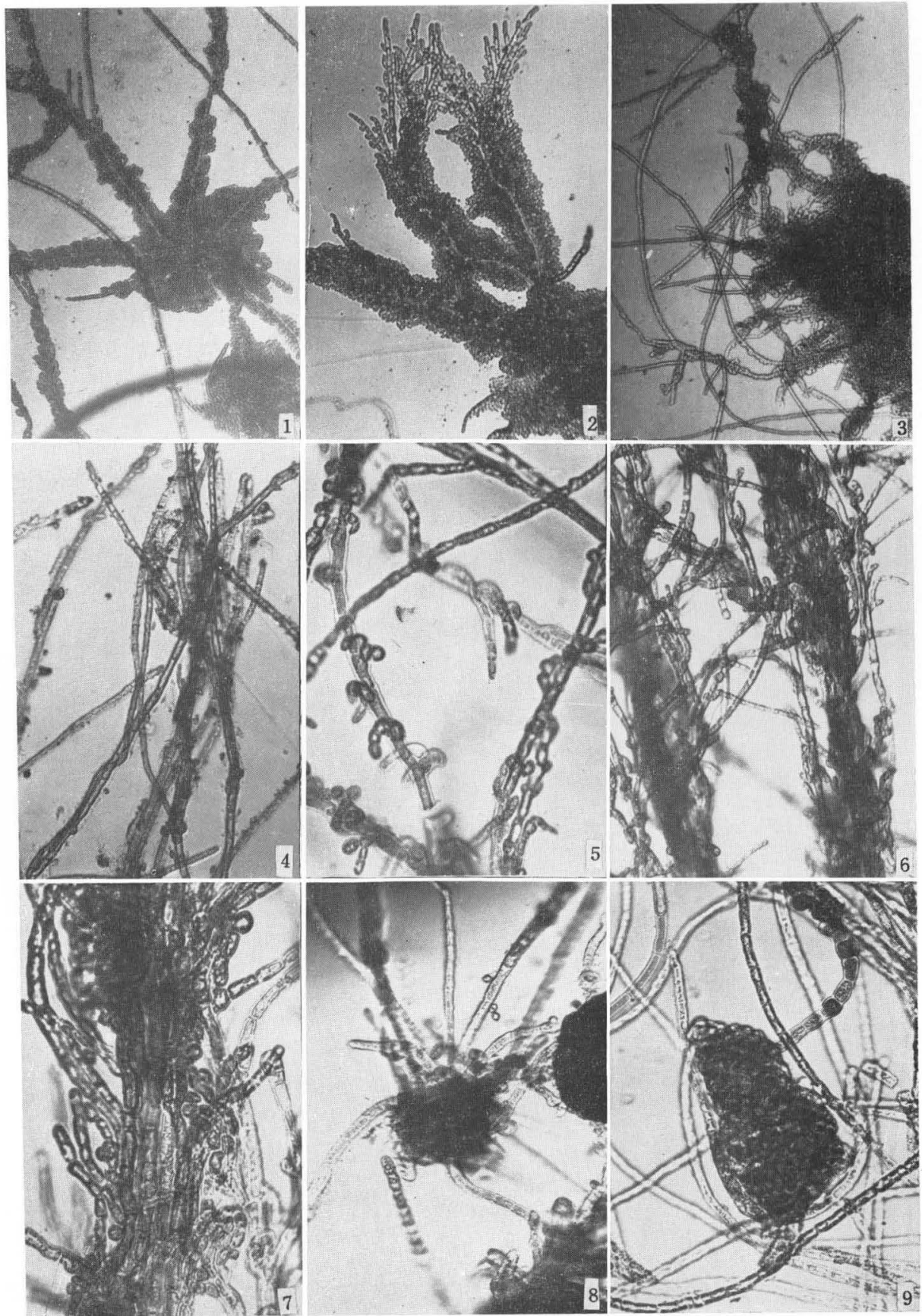

I. Umezaki: Germination of Carpospores of Dudresnaya Japonica 